\title{
OPTIKAI CSIPESZ ÉS NAGY ENERGIÁJÚ ULTRAGYORS LÉZERIMPULZUSOK: A 2018. ÉVI FIZIKAI NOBEL-DÍJAKRÓL
}

\section{OPTICAL TWEEZERS AND HIGH ENERGY ULTRAFAST LASER PULSES: THE 2018 NOBEL PRIZE IN PHYSICS}

\author{
Galajda Péter' , Varjú Katalin² \\ 'PhD, tudományos fömunkatárs, MTA Szegedi Biológiai Kutatóközpont Biofizikai Intézet \\ ${ }^{2} \mathrm{PhD}$, egyetemi docens, Szegedi Tudományegyetem Optikai és Kvantumelektronikai Tanszék, osztályvezető, \\ ELI-ALPS Attoszekundumos Források Osztály, ELI-HU Nonprofit Kft.
}

\begin{abstract}
ÖSSZEFOGLALÁS
2018-ban a fizikai Nobel-díjat Arthur Ashkin az optikai csipesz megalkotásáért, valamint Gérard Mourou és Donna Strickland a nagy energiájú ultrarövid lézerimpulzusok előállításának módszeréért kapta. 1964 óta sok tudós nyerte el a díjat lézerfizikai munkásságáért, ez a sorozat folytatódott most. E cikkben röviden bemutatjuk Ashkin, Mourou és Strickland munkáját, amely a legrangosabb tudományos díj elnyeréséhez vezetett.
\end{abstract}

\section{ABSTRACT}

The 2018 Nobel Prize in Physics has been awarded to Arthur Ashkin for the invention of the optical tweezers, and Gérard Mourou and Donna Strickland for proposing a new method to generate high-intensity, ultra-short laser pulses. Since 1964 numerous researchers have been awarded the Nobel prize for their contribution to laser physics. This series continued in 2018. Here we give a brief overview on the work by Ashkin, Mourou and Strickland that led to the most prestigious award in science.

Kulcsszavak: fizikai Nobel-díj, lézer, optikai csipesz, impulzuserősítés, CPA

Keywords: Nobel Prize in Physics, lasers, optical tweezers, laser pulse amplification, CPA

A Svéd Királyi Tudományos Akadémia 2018. október 2-án jelentette be, hogy a fizikai Nobel-díjat Arthur Ashkin, Gérard Mourou és Donna Strickland megosztva kapják a lézerfizika területén tett jelentős felfedezéseikért (fele-fele arányban Ashkin, illetve a Mourou-Strickland páros). Az indoklás szerint Ashkin az opti- 
kai csipesz megalkotásáért és annak biológiai rendszerekre való alkalmazásáért, Mourou és Strickland pedig a nagy energiájú ultrarövid lézerimpulzusok elő́llítására szolgáló módszer kidolgozásáért nyerte el a díjat. Strickland a harmadik nő, aki fizikai Nobel-dijat kapott, Ashkin pedig 96 évesen a legmagasabb korú díjazott. Ebben az írásban a díjazott eredményeket mutatjuk be.

A lézer feltalálása egy sok milliárd dolláros iparágat alapozott meg. Az egészségügyben, iparban, technológiában nemigen van már olyan ágazat, ahol ne használnának lézereket: tetoválások eltávolításához, sebészeti eljárásokban, daganatos betegségek kezelésében, az iparban precíziós vágásokhoz, hegesztéshez vagy vonalkódok leolvasásához optikai kommunikációban. A lézerek alkalmazása különféle tudományterületeken is elterjedt: a LIGO-berendezésben gravitációs hullámok detektálására használják, lézeres hütéssel érhetőek el a legalacsonyabb hőmérsékletek, lézereket használunk anyagok tulajdonságainak, valamint ultragyors kémiai és fizikai folyamatok vizsgálatához. A lézerek fontos elemei a legmodernebb biológiai mikroszkópiás eljárásoknak is (például: szupernagy felbontású mikroszkópia, többfotonos mikroszkópia).

Mindezen innovációt az alapozta meg, hogy Albert Einstein kidolgozta a sugárzás (fény) kvantumelméletét, leírva a kényszerített emisszió jelenségét (ennek során egy gerjesztett állapotú atomot egy foton arra kényszerít, hogy felesleges energiáját a már meglevő fotonnal azonos állapotú foton formájában sugározza ki - ezáltal erősítve az anyagon áthaladó fényt). Innen származik az elnevezés is, LASER - Light Amplification by Stimulated Emission of Radiation (fényerősítés kényszerített emisszió révén). A kényszerített emisszió gyakorlati alkalmazására az 1940-1950-es években történt kísérlet, amely a mikrohullámú tartományban már müködö MASER-en keresztül végül Alekszandr M. Prohorov, Charles H. Townes és Nyikolaj G. Baszov munkássága nyomán jutott el arra a szintre, hogy Theodore H. Maiman 1960-ban demonstrálta a lézermüködést (Maiman, 1960). Az első néhány évben a lézert úgy bélyegezték, hogy „a solution in search of a problem” (egy megoldás, amely problémára vár). Az azóta eltelt bő ötven évben a lézerek látványosan megtalálták a segítségükkel megoldható problémákat.

Az optikai csipesz ,atyjának” is nevezett Arthur Ashkin lézerekkel a fénynyomást fogta munkára apró testek mozgatásához. A fénynyomás vagy sugárnyomás koncepcióját Kepler már a 17. században felvetette az üstököscsóvák helyzetének magyarázatára, de mennyiségi leírását elöször James C. Maxwell adta meg az elektromágnesség hullámelméletével. Néhány évtizeddel később Einstein kvantumfizikai képbe illesztve határozta meg a foton lendületét. Ezek alapján a sugárnyomás abból ered, hogy ha a sugárzás (például egy fénynyaláb) irányát vagy intenzitását egy tárgy (például tükör) megváltoztatja, akkor a sugárzás lendülete is megváltozik. Newton 3. törvénye szerint ekkor a tárgy (tükör) a sugárzáséval 
ellentétes lendületváltozást szenved, vagyis erő hat rá. A sugárnyomás hatására fellépő erők a mindennapi életben rendkívül kicsik, ezért kísérleti kimutatásuk is nehéz: egy parkoló fekete autóra a napsütés következtében nagyjából egy szúnyog súlyának megfelelő erő hat.

Ashkin egyetemistaként, a II. világháború alatt katonai radarokhoz használt nagy teljesítményủ magnetronok építésén dolgozott. Ekkor gondolt elöször arra, hogy az azokkal keltett mikrohullámok sugárzási nyomása esetleg kis tárgyakat is megmozgathat (URL1).

Később a Bell Telephone Laboratories kutatóintézetben kezdett dolgozni. A híres intézet falai között végzett munkák eddig egyébként kilenc Nobel-díjat eredményeztek. Ashkin egy konferencián hallott - a lézerek gázzal teli rezonátorában megfigyelt részecskemozgásokról szóló - előadás után döntött úgy, hogy a sugárnyomás kimutatásán és alkalmazásán fog dolgozni. Kiszámolta, mekkora erők hatnak egy lézernyalábbal megvilágított, mikroméretű átlátszó golyóra, és rájött, hogy nagyobb erőhatások lépnek fel fókuszált lézernyaláb esetén. A lézerek különleges tulajdonságai lehetővé teszik ugyanis, hogy nagy intenzitású nyalábokat igen kis területre fókuszáljunk. Úttörő munkájában Ashkin (1970) azt tapasztalta, hogy az erős fókuszált lézernyaláb úgy lökte előre a vízben lebegő mikroméretü latexgolyókat, hogy azokat egyúttal a nyaláb közepéhez húzta. A következő kísérletében két egymással szemben haladó lézernyaláb egyenlő erővel ellenkező irányba próbálta lökni a golyókat, így azok már nem mozogtak a nyaláb mentén. Azonban a másik hatás továbbra is müködött, mindkét nyaláb középre húzta a golyókat. Először valósult meg tárgyak (latexgolyók) fénnyel történő stabil rögzítése, vagyis optikai csapdázása. Ashkin felismerte, hogy a kis golyókra kifejtett erők egyik komponense a legnagyobb fényintenzitás, vagyis a nyaláb közepe felé mutat, ezért gyűlnek ott össze a golyók. Ez az ún. gradienserő teszi lehetővé a csapdázást. A másik, a nyaláb terjedési irányába mutató erökomponens, az ún. szórási erő előrelöki a golyókat, tehát nehezíti a csapdázást. Ashkin a szórási erő kiküszöbölésére használt két ellentétes irányú nyalábot.

Egy évvel később már egyetlen, függőlegesen felfelé irányított nyalábbal képes volt 10 mikronos üveggyöngyöket csapdázni. Itt a szórási erőket a gravitációs erő kompenzálta, egy szökőkút tetején kiegyensúlyozott labdához hasonlóan (Ashkin-Dziedzic, 1971). Már ekkor az az ötlete támadt, hogy a lézernyalábok talán még kisebb méretskálán atomok és molekulák manipulálására, csapdázására is használhatók. Az elkezdett munkához csatlakozott Steven Chu is, aki jelentős elörelépéseket ért el, és végül sikeresen alkalmazta a lézernyalábokat atomok hütésére és csapdázására. Chu, valamint William D. Phillips és Claude Cohen-Tannoudji 1997-ben kapta meg a fizikai Nobel-dijat az atomok lézeres hütésének és csapdázásának elméleti és kísérleti kidolgozásáért. Akkor többen adtak hangot annak a véleménynek, hogy hozzájárulása alapján Ashkin szintén megérdemelte volna a díjat. Még egy kitüntetés kapcsolódik ide: az atomok lézeres hütésével 
sikerült az anyag egy különleges állapotának, a Bose-Einstein-kondenzációnak a kísérleti megvalósítása, amelyet 2001-ben díjazott a Svéd Királyi Akadémia. De térjünk vissza a 80-as évekbe! Ashkin meggyőződése volt, hogy egyetlen, igen nagy szögben fókuszált lézernyaláb is képes lehet csapdázásra, a gradienserők legyőzhetik a destabilizáló szórási erőt. Ezt kísérleteiben sikeresen demonstrálta, és megszületett az optikai csipesz ma is használatos, egynyalábos alapvető kísérleti elrendezése (Ashkin et al., 1986). Ashkin azonnal felismerte, hogy ez az eszköz biológiai objektumok csapdázására is alkalmas lehet. Dohánymozaik-vírusokkal kezdett kísérletezni, de végül egy baktériumokkal véletlenül fertőződött mintában sikerült először élő sejteket csapdáznia. A továbbiakban sikeresen csapdáztak élesztő- és baktériumsejteket, és kimutatták, hogy közeli infravörös hullámhosszon müködő lézer használatával a sejtek túlélik a csapdázást (Ashkin et al., 1987). Ez a fontos munka nyitotta meg igazán az utat a biológiai alkalmazások előtt. Ashkin példáját követve egyre több kutatócsoport épített lézercsipeszeket, és kezdte ezeket használni sejtek és biomolekulák tanulmányozására. Kiemelkedően fontos és érdekes eredmények születtek. Kiderült, hogy a lézercsipesz nemcsak csapdázásra, hanem rendkívül kis erök (pikonewton) mérésére is használható a sejtek és molekulák világában: egy csapdázott tárgy fókuszból való elmozdulása alapján meghatározhatók a rá ható erők. Ezzel a módszerrel mérték meg például a baktériumok úszása során múködő molekuláris motorok erejét (Block et al., 1989). Tanulmányozták a vörösvértestek rugalmasságát, aminek köszönhetöen a sejtek a saját méretüknél szükebb hajszálereken is át tudnak jutni (Sleep et al., 1999).

A molekulák világában többek között sikerült megmérni egyes DNS-molekulák rugalmas tulajdonságait a molekulák megnyújtásával (Wang et al., 1997). Jól szemlélteti a lézercsipesz képességeit, hogy egyetlen DNS-molekulára csomót is tudtak kötni (Arai et al., 1999). Rendkívül fontos információkat tudtunk meg az izmok müködésének molekuláris hátteréről. Kiderült például, hogy egyes izomfehérjék lépegetve mozognak az izom-összehúzódás során (Svoboda et al., 1993).

Magyarországon az 1990-es évek végén két intézetben kezdődtek kutatások optikai csipeszek használatával. Kellermayer Miklós vezetésével a Pécsi Tudományegyetem Biofizikai Intézetében, majd a Semmelweis Egyetem Biofizikai és Sugárbiológiai Intézetében izomfehérjék mechanikai tulajdonságait (Kellermayer et al., 1997), valamint a vírusok DNS-kibocsátását (Kellermayer et al., 2018) vizsgálták. A Szegedi Biológiai Kutatóközpont Biofizikai Intézetében Ormos Pál kutatócsoportja a mikrofabrikáció és az optikai csapdázás együttes alkalmazásával készített fénnyel hajtott mikromotorokat (Galajda-Ormos, 2001), illetve a DNS-molekula csavarási tulajdonságait is vizsgálták (Oroszi et al., 2006). A lézercsipeszt mára elterjedt kísérleti eszközként világszerte használják és fejlesztik a biofizikusok. A dinamikus hologramokat használó legújabb berendezések már egyetlen nyalábból számos csapdát állítanak elö, amelyek három dimenzióban 
precízen mozgathatók. Akit közelebbről is érdekelnek ezek a berendezések, azok müködés közben megtekinthetnek és kipróbálhatnak egy lézercsipeszt Szegeden, a Szent-Györgyi Albert Agóra Látványlaboratóriumában (URL2).

Az optikai csipesz remek példája annak, hogy a lézer eszközként használható apró sejtek, sejtalkotók manipulálására. De milyen lehetőségeink vannak magának a lézerimpulzusnak az alakítására?

A lézertechnológia kezdeti fejlődésével elérhetővé vált, hogy a lézeroszcillátor (ami a kényszerített emisszióra képes anyagból és visszacsatoló tükrökből áll: ez az alapegység, ahol a lézerfény keletkezik) a fényt egyre rövidebb impulzusok sorozataként sugározza ki. Az impulzusüzemü működés lehetővé teszi, hogy az oszcillátor átmenetileg tárolja a keletkező fényt, majd azt egyetlen rövid, megnőtt energiájú felvillanás formájában bocsássa ki, ami megnövekedett csúcsteljesítményt biztosít. A lézerfény és az anyag kölcsönhatásának hevességét befolyásoló csúcsteljesítmény növeléséhez két út vezet: vagy a lézerimpulzusban felgyült energiát kell növelni, vagy az impulzus hosszát csökkenteni.

Nagyságrendileg $\mathrm{nJ}\left(10^{-9} \mathrm{~J}\right)$ energiájú impulzusok hosszát 1985-re nanoszekundumról $\left(10^{-9} \mathrm{~s}\right) 100$ femtoszekundumra $\left(10^{-13} \mathrm{~s}\right)$ tudták csökkenteni. Az oszcillátor rövid impulzusait külső erősítőkben akár a $\mathrm{mJ}\left(10^{-3} \mathrm{~J}\right)$ energiára lehetett hizlalni, de itt hosszú ideig egy technológiai akadályba ütközött a fejlődés: a nagy intenzitású (idő- és területegységre jutó energiájú) lézernyaláb roncsolta az erősítőként használt lézeranyagot. Mivel a roncsolás mértéke első közelítésben a fény intenzitásától függ, a nyaláb térbeli kiterjesztésével (amihez egyre nagyobb felületủ optikai elemekre volt szükség, ami jó minőségben igen költséges), illetve az impulzusok időbeli nyújtásával próbálták a problémát orvosolni. Ha viszont az impulzust megnyújtjuk azért, hogy energiáját növelhessük, az a csúcsteljesítmény/intenzitás szempontjából nem jelent haladást, hiszen a nagyobb energiát hosszabb idővel osztjuk.

Pontosan ez az a probléma, amelyre a 2018. évi fizikai Nobel-díjjal elismert Gérard Mourou és Donna Strickland egy ötletes megoldást javasoltak: a lézeroszcillátor kis energiájú, rövid impulzusait elöször megnyújtották (néhány ezerszeresen), a hosszú impulzusokat erősítették (akár milliószorosan), majd az eredeti hosszúságra összenyomták, ezáltal a végső intenzitást képesek voltak öt-hat nagyságrenddel növelni, miközben az erösítés alacsony intenzitáson történik, és elkerülhető az optikai elemek roncsolódása (Strickland-Mourou, 1985). Az elvében egyszerü, de gyakorlati szempontból nagyszerủ megoldás azóta forradalmasította az impulzusüzemü lézerek technológiáját.

A CPA-technológia (Chirped Pulse Amplification - csörpölt/fázismodulált impulzuserősítés), amelyet Mourou és Strickland 1985-ben mutattak be, a lézerimpulzus intenzitásának növelését három lépésben éri el:

1. az impulzus nyújtását az teszi lehetővé, hogy a rövid impulzust alkotó módusokat (frekvenciakomponensek) késleltetik egymáshoz képest. Az így kapott fényimpulzus frekvenciája időben változik, mint a madarak éneké- 
ben a hangmagasság, innen kapta az eljárás a chirp = csiripelés elnevezést. A nyújtáshoz az első kísérletben a rövid impulzust egy hosszú optikai szálba csatolták, amin a módusok a hullámhosszfüggő törésmutató következtében különböző késleltetéssel léptek ki.

2. a megnyújtott impulzusok optikailag gerjesztett lézeranyagban többszöri áthaladással erősödnek, a nyújtás miatt az intenzitás a roncsolási küszöb alatt marad.

3. a megerősített csörpölt impulzusok egy rácsos kompresszoron áthaladva (itt a különböző hullámhosszú módusok különböző utakat járnak be - amihez különböző áthaladási idő tartozik) az 1-es lépésben okozott késleltetést kompenzálva az eredeti hosszra nyomódnak össze.

A CPA-technológia gyorsan elterjedt, és a bemutatása után néhány évvel elkezdődött a PW $\left(10^{15} \mathrm{~W}\right)$ teljesítményü lézerek tervezése. Mourou és Strickland elrendezését több ponton fejlesztették, például a nyújtásra már nem optikai szálat, hanem a kompresszorhoz hasonló optikai rácsos berendezést használnak (Martinez, 1986); az impulzusok végső összenyomását is fejlesztették, és többnyire rácsos kompresszor, „,csörpölt” tükör és anyagi diszperzió kombinációját alkalmazzák; az erősítő fokozatban pedig a lézerelvű erősítés mellett nemlineáris optikai jelenséget is használnak (Dubietis et al., 1992). A lézertechnológia gyorsan fejlődött, és 1999-ben a Lawrence Livermore National Laboratoryban elérték a PW-os $\left(10^{15} \mathrm{~W}\right)$ teljesítményt (Perry et al., 1999). A fejlődés tovább folytatódik, az ELI lézeres kutatóintézetekben, köztük a szegedi ELI-ALPS-nál multi-PW-os lézerrendszereket építenek (Kühn et al., 2017, URL3).

A fejlődés eredményeként egyre rövidebb lézerimpulzusokba egyre több energiát vagyunk képesek koncentrálni. Az impulzusok fókuszálva már sokszorosan meghaladják a $10^{20} \mathrm{~W} / \mathrm{cm}^{2}$ intenzitást, új kutatási területeket nyitva meg: ezen erős terekben az anyag különleges állapotai vizsgálhatók, új ismereteket szerezhetünk a sugárzásról, az erős tér és anyag kölcsönhatásáról, a kvantumelmélet vagy a relativisztikus hatások tekintetében.

A CPA-technika sikerességét mutatja, hogy a nagy intenzitású lézerimpulzusok előállítása egyetemi kutatócsoportok számára megfizethetővé vált, ezáltal a kutatási irányok, az alkalmazások száma robbanásszerüen nő. Néhány alkalmazási irányt az alábbiakban említünk:

Az extrém nagy fényintenzitás lehetővé teszi asztrofizikai jelenségek vagy magfúzió laboratóriumi körülmények között történő vizsgálatát. Az erős lézerteret kihasználva elektron- és iongyorsítók épülnek, és atomok optikai ionizációja révén attoszekundumos impulzusokat hozhatunk létre (Farkas-Tóth, 1992) az elektron viselkedésének vizsgálatához (Calegari et al., 2016). A fényimpulzus rövidsége lehetővé teszi, hogy orvosi vagy ipari alkalmazások esetén az anyag vágása során minimális hőhatás terhelje a környezetet, ezzel csökkentve a környező 
szövetek vagy a megmunkálandó anyag roncsolódását. Ezen alkalmazások közül a Nobel-díj indoklásában a femtoszekundumos lézeres szemsebészetet emelték ki (Loesel et al., 1999).

Nem a 2018-as az első eset, hogy lézerekhez kapcsolódó kutatásért Nobel-díjat ítéltek: 1964-ben (Alekszandr M. Prohorov, Charles H. Townes és Nyikolaj G. Baszov), 1971-ben (Gábor Dénes), 1981-ben (Nicolaas Bloembergen és Arthur L. Schawlow), 1989-ben (Norman F. Ramsey), 1997-ben (Steven Chu, Claude Cohen-Tannoudji és William D. Phillips), 2001-ben (Eric A. Cornell, Wolfgang Ketterle és Carl E. Wieman), 2005-ben (John L. Hall és Theodor W. Hänsch) és 2009-ben (Charles K. Kao) fizikai, 1999-ben (Ahmed Zewail) kémiai Nobel-díjjal értékelték a tudományos eredményeket. Ez a sorozat a jövőben biztosan folytatódni fog.

\section{IRODALOM}

Arai, Y. - Yasuda, R. - Akashi, K. et al. (1999): Tying a Molecular Knot with Optical Tweezers. Nature, 399, 446-448. DOI: 10.1038/20894

Ashkin, A. (1970): Acceleration and Trapping of Particles by Radiation Pressure. Physical Review Letters, 24, 156-159. DOI: 10.1103/PhysRevLett.24.156

Ashkin, A. - Dziedzic, J. M. (1971): Optical Levitation by Radiation Pressure. Applied Physics Letters, 19, 283-285. DOI: 10.1063/1.1655064

Ashkin, A. - Dziedzic, J. M. - Bjorkholm, J. E. et al. (1986): Observation of a Single-beam Gradient Force Optical Trap for Dielectric Particles. Optics Letters, 11, 288-290. DOI: 10.1364/ OL.11.000288

Ashkin, A. - Dziedzic, J. M. - T. Yamane (1987): Optical Trapping and Manipulation of Single Cells Using Infrared Laser Beams. Nature, 330, 769-771.

Block, S. M. - Blair, D. F. - Berg, H. C. (1989): Compliance of Bacterial Flagella Measured with Optical Tweezers. Nature, 338, 514-518. DOI: 10.1038/338514a0, www.nature.com/articles/338514a0

Calegari, F. - Sansone, G. - Stagira, S. et al. (2016): Advances in Attosecond Science. Journal of Physics B - Atomic Molecular and Optical Physics, 49, 062001. DOI: 10.1088/09534075/49/6/062001, http://iopscience.iop.org/article/10.1088/0953-4075/49/6/062001/meta

Dubietis, A. - Jonusauskas, G. - Piskarskas, A. (1992): Powerful Femtosecond Pulse Generation by Chirped and Stretched Pulse Parametric Amplification in BBO Crystal. Optics Communications, 88, 437-440. DOI: 10.1016/0030-4018(92)90070-8

Farkas Gy. - Tóth Cs. (1992): Proposal for Attosecond Light Pulse Generation Using Laser Induced Multiple-harmonic Conversion Processes in Rare Gases. Physics Letters A, 168, 447-450. DOI: 10.1016/0375-9601(92)90534-S

Galajda P. - Ormos P. (2001): Complex Micromachines Produced and Driven by Light. Applied Physics Letters, 78, 249-251. DOI: 10.1063/1.1339258

Kellermayer M. S. Z. - Smith, S. B. - Granzier, H. L. et al. (1997): Folding-Unfolding Transitions in Single Titin Molecules Characterized with Laser Tweezers. Science, 276, 1112-1116. DOI: 10.1126/science. 276.5315 .1112

Kellermayer M. S. Z. - Vörös Z. - Csík G. et al. (2018): Forced Phage Uncorking: Viral DNA Ejection Triggered by a Mechanically Sensitive Switch. Nanoscale, 10, 1898-1904. DOI: 10.1039/ C7NR05897G 
Kühn, S. - Dumergue, M. - Kahaly, S. et al. (2017): The ELI-ALPS Facility: The Next Generation of Attosecond Sources, Journal of Physics B - Atomic Molecular and Optical Physics, 50, 132002. DOI: 10.1088/1361-6455/aa6ee8, http://iopscience.iop.org/article/10.1088/1361-6455/ aa6ee8

Loesel, F. H. - Kurtz, R. M. - Horvath, C. et al. (1999): Ultraprecise Medical Applications with Ultrafast Lasers: Corneal Surgery with Femtosecond Lasers. Proceedings of the SPIE, 3564, 86-93. DOI: $10.1117 / 12.339141$

Maiman, T. H. (1960): Stimulated Optical Radiation in Ruby Masers. Nature, 187, 493-494. DOI: 10.1038/187493a0, https:/www.researchgate.net/publication/224884409_Stimulated_optical_ radiation_in_ruby_masers

Martinez, O. E. (1986): Grating and Prism Compressors in the Case of Finite Beam Size. Journal of the Optical Society of America B, 3, 929-934. DOI: 10.1364/JOSAB.3.000929

Oroszi L. - Galajda P. - Kirei H. et al. (2006): Direct Measurement of Torque in an Optical Trap and Its Application To Double-strand DNA. Physical Review Letters, 97, 1-4. DOI: 10.1103/ PhysRevLett.97.058301, https://www.researchgate.net/publication/6769197_Direct_Measurement_of_Torque_in_an_Optical_Trap_and_Its_Application_to_Double-Strand_DNA

Perry, M. D. - Pennington, D. - Stuart, B. C. et al. (1999): Petawatt Laser Pulses. Optics Letters, 24, 160-162. DOI: 10.1364/OL.24.000160

Sleep, J. - Wilson, D. - Simmons, R. et al. (1999): Elasticity of the Red Cell Membrane and Its Relation to Hemolytic Disorders: An Optical Tweezers Study. Biophysical Journal, 77, 3085-3095. DOI: 10.1016/S0006-3495(99)77139-0, www.sciencedirect.com/science/article/pii/ S0006349599771390?via\%3Dihub

Strickland, D. - Mourou, G. (1985): Compression of Amplified Chirped Optical Pulses. Optics Communications, 56, 219-221. DOI: 10.1016/0030-4018(85)90120-8, www.sciencedirect.com/ science/article/pii/0030401885901208

Svoboda, K. - Schmidt, C. F. - Schnapp, B. J. et al. (1993): Direct Observation of Kinesin Stepping by Optical Trapping Interferometry. Nature, 365, 721-727. DOI: 10.1038/365721a0

Wang, M. D. - Yin, H. - Landick, R. et al. (1997): Stretching DNA with Optical Tweezers. Biophysical Journal, 72, 1335-1346. DOI: 10.1016/S0006-3495(97)78780-0, www.ncbi.nlm.nih.gov/ pmc/articles/PMC1184516/pdf/biophysj00036-0355.pdf

URL1: He Wrote the Book on Atom Trapping, web.archive.org/web/20050411192741/http://www. bell-labs.com/user/feature/archives/ashkin/

URL2: Interaktív fizikai kísérletbemutató, http://www.agoraszeged.hu/program/interaktiv-fizikai-kiserletbemutato

URL3: A három ELI-intézetet összefogó szervezetről: www.eli-alps.hu/hu/Rolunk/ELI-DC; a szegedi kutatóintézet lézereiről: www.eli-alps.hu/hu/Kutatastechnologia/Lezerek 